\title{
VLIV VYBRANÝCH DEMOGRAFICKÝCH CHARAKTERISTIK NA VOLEBNÍ CHOVÁNÍ NA SLOVENSKU V MEZIVÁLEČNÉM OBDOBÍ
}

\author{
Vojtěch Przybyla* \\ * Univerzita Komenského v Bratislave, Prírodovedecká fakulta, Katedra ekonomickej a sociálnej geografie, \\ demografie a územného rozvoja, Mlynská dolina, Ilkovičova 6, 84215 Bratislava, \\ vojtech.przybyla@uniba.sk
}

\begin{abstract}
The influence of selected demographic characteristics on electoral behaviour in Slovakia in the interwar period

Studying the electoral behaviour of voters is a basic prerequisite for understanding the results of the elections both in the present and in the past. The main goal of our paper is to determine the population's electoral preferences based on demographic indicators. We have considered, as the main indicators, nationality and religion. We have compared the findings with the previous works of historians and geographers who have reflected on this topic and who have considered these factors to be the main determinants of electoral support. But can we truly generalize this phenomenon? Although the electoral preference of the electorate during the first Czechoslovak Republic was significantly influenced by its national structure and religion in all parliamentary elections, there could have been political parties whose electoral support had no influence. Our study follows the evolution of voter's preference during 15 years and we are primarily interested in the elections to the Chamber of Deputies of the National Assembly of Czechoslovakia, which took place in April 1920, November 1925, October 1929 and May 1935. The area of research is bounded by the territory of today's Slovak Republic. To be able to interpret the obtained primary data, we used in this work a set of mathematical and statistical methods usually used in electoral geography as correlation and regression analysis.
\end{abstract}

Key words: parliamentary elections, nationality, religion, interwar period, Czechoslovakia

\section{ÚVOD}

Volby jako objekt vědeckého bádání, a tedy volební geografie jako vědní obor, který je zkoumá, je poměrně nová záležitost, jež se v našem středoevropském prostoru etablovala jako subdisciplína politické geografie poměrně nedávno. $\mathrm{V}$ souvislosti s tímto fenoménem vnímáme akutní potřebu představovat nejenom aktuální zhodnocení volebního chování obyvatel, což se v současném výzkumu děje nejčastěji, ale rovněž nahlédnout do vzdálenější minulosti a zaměřit se na politické chování našich předků. Je potřeba si uvědomit úskalí této problematiky, jelikož nemáme $\mathrm{k}$ dispozici takové množství pramenů a dat, jaké máme $\mathrm{k}$ studiu dnešní doby. Přesto všechno považujeme téma historické volební geografie za důležitý př́íspěvek do mozaiky politického vývoje společnosti, a to nejenom na Slovensku, ale kdekoliv na světě.

Ve střední a východní Evropě se volební geografie, oproti západní Evropě a USA, vyprofilovala až o desítky let později, a to po skončení studené války a pádu komunistických režimů na přelomu 80. a 90. let minulého století. Z toho vyplývá, že systematické studium volební problematiky začalo např. v Československu až po sametové revoluci a uskutečnění svobodných voleb v roce 1990. Jako jedni 
z prvních nastínili možné přístupy práce s volebními daty Jehlička a Sýkora (1991) a Blažek a Kostelecký (1991), v př́ípadě Jehličky a Sýkory v návaznosti na volby prvorepublikové. Analýza historických voleb má však v literatuře postkomunistických zemí poněkud marginální význam. Kromě Česka (např. Kostelecký et al. 2014 a Gregor 2015) se historickému kontextu prostorových vzorců volebního chování věnují práce některých polských autorů (Zarycki 2000 a 2015 a Kowalski 2003). Ojedinělé pokusy sledujeme i např. v Rusku (Perepechko et al. 2007). Vliv minulosti na současné chování elektorátu v podobě problematiky tzv. fantómových hranic v Polsku představuje Jańczak (2015). Stejné téma aplikované na české prostředí pak přináší Šimon (2015). Poněkud překvapivě nalézáme téma historické volební geografie Československa i mimo náš středoevropský prostor, a to konkrétně v americkém prostředí ve článku Kopsteina a Wittenberga (2009), analyzující neliberální strany v letech 1929 - 1935.

Na Slovensku se první významnější práce objevují až po získání samostatnosti $\mathrm{v}$ roce 1993. Baráth et al. (1995) představují první komparativní článek, a to analýzu stability volební podpory vybraných politických stran na základě výsledků voleb v letech 1990, 1992 a 1994. Zásadní prací ve slovenské literatuře, zkoumající chování elektorátu, je publikace Krivý et al. (1996) pod názvem Slovensko a jeho regiony: sociokulturní souvislosti volebního chování. Již z názvu vyplývá př́klon $\mathrm{k}$ sociologickému řešení tématu. Studie nám ukazuje politické inklinace obyvatelstva na základě třech hlavních faktorů: národnosti, náboženského vyznání a vzdělanosti. Cenná je především snaha o postřehnutí regionální diferenciace problému. Ostatně Vladimír Krivý se věnuje volbám dlouhodobě (viz např. Krivý 2000, 2012 a 2014), i ve spolupráci s českými autory (Kostelecký a Krivý 2015). Na přelomu století spatřujeme další rozvoj tohoto tématu a na vědecké scéně se objevují noví autoři studující volební chování obyvatel, jako např́klad Mariot (1999), Mesežnikov (2002), Szöllös (2006) aj. V poslední dekádě do popředí vystupuje především Madleňák (2012) a Plešivčák (2017). Diapazon těchto autorů ovšem nepřesahuje vymezené období 1990 - současnost a detailní prozkoumání meziválečných voleb a posledních demokratických voleb v roce 1946 tak z geografického pohledu citelně chybí. Za výjimky můžeme považovat několik prací z poslední doby, a to např́íklad články autorských dvojic Bahna a Krivý (2016) a Madleňák a Balážovič (2018). Jedná se však o sledování parciálních částí této problematiky, v obou př́ípadech o parlamentní volby roku 1929.

Z pohledu historiků téma meziválečné politické situace sledovala např́iklad monografie Marka et al. (2000) věnující se přehledu politických stran na území českých zemí v letech 1861 - 1998 a na ni navazující dvoudílná encyklopedie Malíře a Marka (2005), která zpracovává všechna významnější politická seskupení na území českých zemí a Československa formou hesel. Ve slovenském prostředí se politickým stranám v období let 1860 - 1989 věnoval Lipták (1992), prvorepublikovým pak Zemko (2004), Hanula (2011) nebo Osyková (2012).

Předkládaná studie sleduje vývoj volebních preferencí obyvatel v horizontu 15 let. V tomto čase proběhlo $\mathrm{v}$ Československu několik voleb různých stupňů, nás však primárně zajímají volby do Poslanecké sněmovny Národního shromáždění RČS, které se uskutečnily v dubnu 1920, listopadu 1925, ř́ijnu 1929 a květnu 1935. Oblast výzkumu je ohraničena územím dnešní Slovenské republiky a jak již bylo řečeno, komplexní studie, která by zkoumala všechny meziválečné parlamentní volby z geografického hlediska, ve slovenské literatuře absentuje. Hlavním cílem našeho př́spěvku je zjistit volební preference obyvatel v závislosti na diferenčních 
demografických ukazovatelích. Zjištěné poznatky jsme se rozhodli komparovat s dosavadními pracemi historiků a geografů, kteří toto téma, a to alespoň parciálně, reflektovali. Do úvahy jsme jako hlavní indikátory vzali národnost a náboženské vyznání. O důležitosti těchto dvou faktorů hovoří např́íklad Lipták (1992), jenž vyjmenovává tři hlavní pilíre úspěšnosti politických stran za první republiky (národnost, náboženství a sociální status). Opravdu však můžeme tento jev zobecnit? Nenalezneme tzv. všeobjímající stranu, (catch-all party), které se podařilo zaujmout široké spektrum voličů napříč tehdejší společností? Stanovili jsme si proto následující výzkumnou hypotézu: Ačkoliv volební preference elektorátu v období první Ceskoslovenské republiky byly ve všech parlamentních volbách výrazně ovlivněny jeho národnostní strukturou a náboženským vyznáním, mohly existovat politické strany, na jejichž volební podporu neměl tento faktor vliv.

Je potřebné říci, že stranicko-politický systém nového československého státu se zformoval kontinuálním pokračováním mnoha českých politických stran, působících již za Rakouska-Uherska (Cabada a Šanc 2005). Tímto vzniká asymetrická situace, jelikož vlivem násilné mad'arizace nebyly na Slovensku př́znivé okolnosti pro větší množství slovenských stran, a po vzniku společné republiky tak zde existuje pouze jediná Slovenská národná strana, zahrnující všechny proudy slovenské politiky (Lipták 1992). Toho využívají politické strany české, které se v průběhu let 1918 - 1919 přejmenovávají na „československé“ (avšak ve skutečnosti jejich politiku nadále realizují dosavadní české politické elity) a zakládají ve slovenském prostoru své stranické aparáty (Cabada a Šanc 2005). Symbolem stranicko-politického systému meziválečného období byla jeho značná fragmentace, z hlediska typologie Sartoriho (1976) ho lze označit jako extrémní multipartismus. Enormní množství politických stran a jen v omezené míře existující volební klauzule (Zemko 2008), která by stanovila přirozený práh pro vstup do parlamentu, komplikovala sestavení vlád a nutila jednotlivé strany ke kompromisům, které zvyšovaly jejich koaliční potenciál. S výjimkou konjukturního období ve druhé polovině 20 . let tak vznikaly vlády nestandardně zahrnující různé strany pravo-levého spektra, nazývané jako „,Všenárodní“ nebo „široké“ koalice, čímž se stát vzdaloval od principů parlamentní demokracie západního typu charakteristického střídáním levo-středých a pravostředých vládních formací (Kárník 2008). Pokud bychom chtěli ve stručnosti shrnout dopady volebního systému na stranicko-politický systém ČSR, vnímáme několik jednoznačných charakteristik: velký počet politických stran, vytváření koaličních vlád, malá obměna politických elit a strnulost stranických programů, silný vliv politických stran na chod státu a pragocentristické tendence.

\section{POUŽITÁ METODIKA}

Vzhledem k neexistenci elektronické podoby volebních výsledků v námi sledovaném období bylo nutné využít tištěných zdrojů a ty poté ručně přepsat do počítačové podoby. Data byla získána z publikací Státního úrada statistického (SÚS), resp. jeho edice Československá statistika. Zde ovšem musíme poukázat na poněkud nevhodně zvolený styl zpracování těchto pramenů, které vycházejí z premisy, že hlavní statistickou jednotkou je 22 volebních krajů (z toho na Slovensku sedm: Trnava, Nové Zámky, Turčiansky Sv. Martin, Banská Bystrica, Liptovský Sv. Mikuláš, Košice a Prešov). Ty ovšem nerespektují hranice tehdejších okresủ. Znamená to, že naprríklad politický okres Modrý Kameň má zařazených 18 obcí do volebního kraje Nové Zámky, 8 obcí do volebního kraje Banská Bystrica a 45 obcí do volebního kraje Košice. K docílení co nejpřesnějš́ího zhodnocení demografických 
ukazatelů jsme užili následujícího klíče: pro volby 1920 a 1925 se zohledňují data ze sčítání lidu 1921, pro volby 1929 a 1935 data ze sčítání lidu 1930. Do naší studie jsme zahrnuli ty politické strany, které $\mathrm{v}$ předmětných parlamentních volbách kandidovaly ve všech volebních krajích.

Abychom byli schopni získaná primární data interpretovat, využili jsme v této práci soubor matematicko-statistických metod obvykle užívaných ve volební geografii. Jedním ze způsobů sledování vlivu sociálně-ekonomického prostředí na volební chování obyvatel je právě i korelační analýza, a to prostřednictvím různých korelačních koeficientů (Watrel et al. 2018). Nejčastěji se v tomto př́ípadě užívá Pearsonův korelační koeficient (r). Ten je chápán jako lineární párový korelační koeficient, jenž zaznamenává míru asociace dvou proměnných. Velikost korelačního koeficientu se projeví ve tvaru sdružené hustoty pravděpodobnosti. Rozmezí hodnot korelace je od -1 do +1 . V případě hodnoty 0 chybí statistická souvislost mezi oběma proměnnými (Hendl 2012). Vlivem př́itomností odlehlých hodnot nebo třetí (skryté) proměnné může dojít k nadhodnocení korelačního koeficientu. Pro tyto účely se využívá Spearmanův korelační koeficient (rs), což je pořadový nelineární korelační koeficient, vycházející nikoli z hodnot, ale z jejich pořadí. Tento koeficient tak porovnává, do jaké míry je uspořádání analyzovaných dat podle veličiny X stejné jako podle veličiny Y. Hodnoty koeficientu se rovněž pohybují v rozmezí od -1 do +1 . Hodnot kolem nuly nabývá Spearmanův korelační koeficient $\mathrm{v}$ př́ípadě, že pořadí hodnot $\mathrm{X}$ a $\mathrm{Y}$ jsou náhodně zpřeházená a mezi sledovanými veličinami není žádný vztah. Naopak hodnot -1 do +1 nabývá Spearmanův korelační koeficient $\mathrm{v}$ prrípadě, že jedna $\mathrm{z}$ veličin je monotónní funkcí druhé veličiny (Hendl 2012). Protože korelace je míra souvislosti, můžeme její sílu popsat i verbálně. Zatímco Cohen (1988) navrhuje pro absolutní hodnotu r tři základní kategorie, Evans (1996) uvádí až 5 kategorií, a to „velmi slabá“ (hodnota $\pm 0,00$ - 0,19), „slabá“ (hodnota $\pm 0,20$ - 0,39), „střední“ (hodnota $\pm 0,40-0,59)$, „silná“ (hodnota $\pm 0,60$ - 0,79) a ,velmi silná“ (hodnota $\pm 0,80-1,00)$. Korelace střední až velmi silná je v př́lohových tabulkách zvýrazněna.

Jestliže jsme prokázali závislost sledovaných veličin, může nás zajímat tvar této závislosti. Matematickým popisem závislosti veličin se zabývá regresní analýza. V naší práci jsme se rozhodli použít jednoduchou lineární regresi, kde podíl hlasů pro vybrané politické strany v jednotlivých volbách (tj. závisle proměnná) je vysvětlován za pomocí nezávisle proměnných charakterizujících národnost a náboženské vyznání. Koeficienty modelu jsou hledány tak, aby byly minimalizovány odchylky skutečných hodnot od proloženého trendu (model). K tomu došlo skrze tzv. metodu nejmenších čtverců (OLS), jež se snaží minimalizovat součet jednotlivých odchylek umocněných na druhou (Hendl 2012). V případě regresního modelu jsme jako referenční kategorie brali československou národnost a ř́mskokatolické vyznání a současně jsme naše výpočty „očistili“" od stanovených kategorií „ostatní“ a ,jiné“. Datové analýzy jsme provedli prostřednictvím softwarových programů $\mathrm{R}$ 3.3.1 a Statistica 13.

Výběr územní úrovně je při zkoumání voleb jedním z nejdůležitějších faktorů. Nejpodrobnější informace můžeme získat z volebních okrsků, avšak ve větších sídlech dochází téměř každé volby k úpravám jejich počtu a velikosti, tudíž je dlouhodobá analýza na této úrovni těžko realizovatelná. Spatřujeme ale souvztažnost mezi zvětšující se velikostí územní úrovně a zkreslením výsledných dat. Logickou záležitostí je snaha nalézt nejdéle kontinuálně fungující územní celek. V našem př́padě se jedná o politický okres (PO), administrativní jednotku existující do roku 
1949, v námi sledovaném období s minimálními změnami. Pro potřeby této práce se užívá rozdělení administrativních okresů k 1. 12. 1928, tedy k datu, kdy vstoupil v platnost zákon o organizaci politické správy (č. 125/1927 Sb.). Aby bylo dosaženo požadovaného stavu, došlo $\mathrm{v}$ několika př́ípadech $\mathrm{k}$ modifikaci tehdy platného správního členění. Kromě již zmíněné edice Československá statistika z dílny SUS byl v našem článku rovněž využit i datový soubor ze Slovenského archívu sociálnych dát (SASD 2014), který zpracovává výsledky voleb za roky 1929 a 1935 až do úrovně obcí.

\section{NÁRODNOST A NÁBOŽENSKÉ VYZNÁNÍ JAKO FAKTOR OVLIVNUUJÍCÍ VOLEBNÍ CHOVÁNÍ ELEKTORÁTU}

Meziválečná ČSR byla mnohonárodnostním státem se silným procentuálním podílem menšin na celkovém počtu obyvatel a zároveň státem s poměrně velkým počtem uznaných církví. Na základě hodnot Pearsonova a Spearmanova korelačního koeficientu a lineární regrese jsme se proto snažili nalézt souvstažnost mezi volební podporou politických stran, národností a náboženským vyznáním. Do našich výpočtů jsme zařadili 5 významných národností, zastoupených v tehdejší slovenské populaci, a to Čechoslováky (70,4 \% dle sčítání lidu 1930), Mad'ary (17,2 \%), Němce $(4,4 \%)$, Rusíny $(2,7 \%)$ a Židy (1,9 \%). Další národnosti $(3,2 \%)$ jsou zahrnuty ve skupině „ostatní“. V př́ípadě sledování hodnot náboženské příslušnosti a volební podpory jsme vybrali rovněž 5 kategorií, a to největší církev (římskokatolickou), církev dominantní ve východní části země (řeckokatolickou), nejsilnější protestantskou církev (evangelickou augsburského vyznání), církev nacionálně orientovanou (československou husitskou) a obyvatelstvo bez vyznání. Ostatní náboženství jsou skryta v kategorii ,jiné“.

První parlamentní volby roku 1920 jsou na Slovensku charakteristické omezenou volební soutěží, jelikož zde kandidovalo jen devět politických stran (z toho jen pět na celém území). Výrazným náskokem (510 341 hlasů, tj. 35,05 \%) zvítězila Československá sociálně-demokratická strana dělnická (ČSDSD), následovaná Slovenskou národnou a rol’níckou stranou (SNRS) a Československou stranou lidovou (ČSL). Výsledky voleb ovlivnil i fakt, že Hlinkova slovenská l'udová strana (HSLSS) kandidovala v koalici a pod hlavičkou ČSL, což lidovcům zajistilo nejlepší výsledek v tomto období.

Tabulka 1 představuje hodnocení lineární a nelineární závislosti mezi volebními výsledky a hodnotami námi zvolených indikátorů. $\mathrm{V}$ prŕípadě národnosti vidíme u ČSDSD i Československé strany národně-socialistické (ČSNS) slabý vliv této kategorie na volební preference. U sociální demokracie se tento výsledek ukazuje i v korelaci s vyznáním. Znamená to tedy, že tyto strany podpořili občané bez ohledu na svou národnostní př́slušnost (resp. vyznání). V prípadě národních socialistů však pracujeme s velmi malým vzorkem obyvatelstva (volební zisk 29564 hlasů, tj. 2,20\%). V př́ípadě ČSDSD jsme přistoupili k výpočtu regresního modelu, jehož výsledky (tab. 2) jakoukoliv významnost vztahů mezi volebními výsledky ČSDSD a demografickými faktory neukazují. Pokud se podíváme na další strany, u ČSL pozorujeme pozitivní korelaci $\mathrm{s}$ čs. národností a zároveň negativní korelaci $\mathrm{s}$ podílem obyvatel patřících $\mathrm{k}$ mad'arské menšině. Ovlivněno to může být sestavením společné kandidátní listiny čs. lidové strany s Hlinkovou slovenskou l'udovou stranou (HSL'S) a její protimad'arskou rétorikou. Z logiky věci pak opačná situace nastává u mad’arské Zemské křest’ansko-sociální strany (ZKSS), kde je patrná silná 
negativní korelace $\mathrm{s}$ čs. národností a pozitivní s mad'arskou. Za zmínku stojí též zjištěná střední kladná korelace Židovské strany (ŽS) s rusínským etnikem, a to v př́ípadě užití Pearsonova korelačního koeficientu. Jelikož židovská a rusínská národnost tvořily zejména na východě Slovenska $v$ některých okresech značnou část obyvatelstva, mohlo jejich společné soužití ovlivnit tuto preferenci (a zkreslit tak výsledné hodnoty), a to včetně střední kladné korelace Židovské strany s řeckokatolickou církví, $\mathrm{k}$ níž se v drtivé většině hlásili př́slušníci rusínské národnosti.

Tab. 1. Hodnoty korelačních koeficientů mezi volebními výsledky vybraných politických strana národnostním/náboženským složením obyvatel $v$ roce 1920

\begin{tabular}{|c|c|c|c|c|c|c|c|}
\hline \multirow{2}{*}{ Politická strana } & \multirow{2}{*}{$\begin{array}{l}\text { Korelační } \\
\text { koeficient }\end{array}$} & \multicolumn{6}{|c|}{ Národnost } \\
\hline & & čs. & mad'. & něm. & žid. & rus. & ostatní \\
\hline \multirow{2}{*}{ ČSDSD } & Pearson & 0,259 & $-0,332$ & 0,119 & $-0,067$ & 0,152 & 0,149 \\
\hline & Spearman & 0,173 & $-0,121$ & 0,096 & $-0,184$ & 0,229 & 0,195 \\
\hline \multirow{2}{*}{$\breve{C S L}$} & Pearson & 0,621 & $-0,582$ & 0,004 & $-0,066$ & $-0,065$ & $-0,253$ \\
\hline & Spearman & 0,565 & $-0,534$ & 0,209 & 0,053 & $-0,035$ & $-0,243$ \\
\hline \multirow{2}{*}{ ČSNS } & Pearson & 0,021 & $-0,048$ & 0,220 & 0,103 & $-0,112$ & 0,050 \\
\hline & Spearman & $-0,044$ & 0,130 & 0,309 & $-0,073$ & 0,082 & 0,037 \\
\hline \multirow{2}{*}{ SNRS } & Pearson & 0,461 & $-0,451$ & $-0,133$ & 0,293 & 0,070 & 0,099 \\
\hline & Spearman & 0,500 & $-0,430$ & $-0,107$ & 0,288 & 0,058 & $-0,086$ \\
\hline \multirow{2}{*}{ ZKSS } & Pearson & $-0,814$ & 0,787 & 0,198 & $-0,038$ & $-0,168$ & 0,104 \\
\hline & Spearman & $-0,761$ & 0,804 & 0,122 & $-0,088$ & $-0,001$ & 0,190 \\
\hline \multirow{2}{*}{ ŽS } & Pearson & $-0,176$ & 0,020 & $-0,152$ & 0,848 & 0,490 & 0,297 \\
\hline & Spearman & $-0,200$ & 0,084 & $-0,142$ & 0,775 & 0,338 & $-0,010$ \\
\hline \multirow[b]{2}{*}{ Politická strana } & \multirow[b]{2}{*}{$\begin{array}{l}\text { Korelační } \\
\text { koeficient }\end{array}$} & \multicolumn{6}{|c|}{ Náboženské vyznání } \\
\hline & & řím. kat. & řec. kat. & $\begin{array}{l}\text { evang. } \\
\text { augsb. }\end{array}$ & čs. hus. & bez vyznání & jiné \\
\hline \multirow{2}{*}{ ČSDSD } & Pearson & $-0,162$ & 0,110 & 0,220 & 0,016 & 0,001 & $-0,019$ \\
\hline & Spearman & $-0,118$ & 0,238 & 0,074 & 0,056 & 0,217 & $-0,142$ \\
\hline \multirow{2}{*}{ ČSL } & Pearson & 0,371 & $-0,149$ & $-0,038$ & $-0,016$ & 0,005 & $-0,376$ \\
\hline & Spearman & 0,350 & $-0,198$ & 0,167 & 0,068 & 0,133 & $-0,474$ \\
\hline \multirow{2}{*}{ ČSNS } & Pearson & $-0,077$ & $-0,049$ & 0,106 & 0,111 & 0,574 & $-0,016$ \\
\hline & Spearman & $-0,076$ & 0,137 & 0,391 & 0,452 & 0,257 & $-0,031$ \\
\hline \multirow{2}{*}{ SNRS } & Pearson & $-0,289$ & 0,191 & 0,324 & 0,136 & $-0,170$ & 0,030 \\
\hline & Spearman & $-0,196$ & $-0,042$ & 0,043 & $-0,066$ & 0,277 & $-0,185$ \\
\hline \multirow{2}{*}{ ZKSS } & Pearson & $-0,137$ & $-0,110$ & $-0,123$ & $-0,041$ & 0,161 & 0,260 \\
\hline & Spearman & $-0,156$ & 0,146 & 0,037 & 0,144 & $-0,050$ & 0,419 \\
\hline \multirow{2}{*}{ ŽS } & Pearson & $-0,363$ & 0,596 & $-0,243$ & 0,016 & $-0,027$ & 0,621 \\
\hline & Spearman & $-0,240$ & 0,327 & 0,046 & $-0,078$ & $-0,207$ & 0,501 \\
\hline
\end{tabular}

Vysvětlivky: čs. - československá, mad'. - mad’arská, něm. - německá, žid.- židovská, rus. - rusínská; řím. kat. - římskokatolické, řec. kat. - řeckokatolické, evang. augsb. - evangelické augsburského vyznání, čs. hus. - československé husitské Zdroj: SÚS (1922 a 1924), vlastní výpočty autora. 
Tab. 2. Parametry lineární regrese (OLS) mezi volebními výsledky ČSDSD (závisle proměnná) a národnostním/náboženským složením obyvatel v roce 1920

\begin{tabular}{lccccc}
\hline \multicolumn{1}{c}{ Nezávislé proměnné } & $\begin{array}{c}\text { Odhad } \\
\text { parametrů }\end{array}$ & $\begin{array}{c}\text { Standardní } \\
\text { chyba }\end{array}$ & t hodnota & $\operatorname{Pr}(>|t|)$ & $\begin{array}{c}\text { Významnost } \\
\text { vztahu }\end{array}$ \\
\hline (konstanta) & 39,334 & 5,368 & 7,327 & 0,000 & $* * *$ \\
mad'arská & $-0,152$ & 0,073 & $-2,074$ & 0,142 & \\
německá & 0,092 & 0,230 & 0,402 & 0,689 & \\
židovská & $-2,651$ & 1,630 & $-1,626$ & 0,109 & \\
rusínská & 0,223 & 0,481 & 0,464 & 0,645 & \\
řekkokatolická & 0,262 & 0,343 & 0,766 & 0,447 & \\
čs. husitská & 5,424 & 17,457 & 0,311 & 0,757 & \\
evangelická augsb. & 0,182 & 0,131 & 1,383 & 0,172 & \\
bez vyznání & 2,616 & 12,235 & 0,214 & 0,831 & \\
\hline
\end{tabular}

Zdroj: SÚS (1922 a 1924), vlastní výpočty autora.

Druhé parlamentní volby, uskutečněné roku 1925, znamenají výrazné překreslení volební mapy. Minule vítězná sociální demokracie naprosto propadla a obdržela pouhých 60 tisíc hlasů, tzn. ztratila zhruba 450 tisíc hlasů (sic!). Volby suverénně vyhrála HSLS, následovaná agrárníky a komunisty. Výpočty korelačních koeficientů přinášejí poměrně častou kladnou korelaci židovské národnosti s volební podporou vícero politických stran (viz tab. 3). Dalším výsledkem, který stojí za pozornost, je střední záporná korelace (r) Komunistické strany Ceskoslovenska (KSČ) s podílem obyvatel čs. národnosti, a naopak střední (r) až silná (rs) pozitivní korelace $\mathrm{s}$ národností mad'arskou. To nás přivádí $\mathrm{k}$ myšlence o silné podpoře komunistů mezi Mad'ary, a proto jsme ji ověřili i sestavením regresního modelu (tab. 4). Z něj vyplývá, že mezi těmito dvěma proměnnými existuje silná vazba, $\mathrm{v}$ řeči čísel tak každé procento mad'arské národnosti v daném okrese přidalo komunistům $v$ těchto volbách $0,16 \%$.

Pozitivní korelaci sledujeme u Československé národní demokracie (ČSND) a rusínské menšiny. To pravděpodobně způsobila volební koalice ČSND s některými rusínskými stranami, což patrně pozitivně ovlivnilo i židovské voliče ve vztahu $\mathrm{k}$ této straně. U československých stran sledujeme očekávanou zápornou korelaci $\mathrm{k}$ podílu Mad'arů a dále pozitivní korelaci k podílu Rusínů a Židů v populaci. U Republikánské strany zemědělského a malorolnického lidu (RSZML), nejvýznamnější parlamentní strany v průběhu celé existence první čs. republiky, sledujeme negativní korelaci s podílem obyvatel hlásících se k rrímskokatolické církvi, ale naopak pozitivní korelaci s řeckokatolíky a evangelíky. Zjištěný trend ve své monografii potvrzuje i Hanula (2011). Silnou pozitivní korelaci vidíme mezi Slovenskou národnou stranou (SNS) a evangelíky, kteří se po odchodu hlinkových katolíků stali dominantní skupinou v této straně. Proto můžeme pozorovat ve stejném čase i jejich negativní korelaci $\mathrm{k}$ podílu obyvatel hlásících se $\mathrm{k}$ ř́mskokatolické víře. Jedinou stranou, u které se neprokázala korelace s žádnou národnostní skupinou, byla tentokrát ČSDSD. Střední zápornou korelaci (r i rs) volebních preferencí této strany však sledujeme s náboženským vyznáním a jeho kategorií jiné, kde se ukrývají méně zastoupené církve, jako pravoslavní nebo starokatolíci. V případě lineární regrese (tab. 5) nalézáme záporný vztah s mad’arskou menšinou, kdy každé procento mad'arského etnika v daném okrese ubralo straně $0,03 \%$ hlasů. 
Tab. 3. Hodnoty korelačních koeficientů mezi volebními výsledky vybraných politických stran a národnostním/náboženským složením obyvatel $\mathrm{v}$ roce 1925

\begin{tabular}{|c|c|c|c|c|c|c|c|}
\hline \multirow{2}{*}{ Politická strana } & \multirow{2}{*}{$\begin{array}{l}\text { Korelační } \\
\text { koeficient }\end{array}$} & \multicolumn{6}{|c|}{ Národnost } \\
\hline & & čs. & mad'. & něm. & žid. & rus. & ostatní \\
\hline \multirow{2}{*}{ ČSDSD } & Pearson & 0,340 & $-0,284$ & 0,172 & $-0,277$ & $-0,276$ & $-0,280$ \\
\hline & Spearman & 0,388 & $-0,163$ & 0,201 & $-0,289$ & $-0,289$ & $-0,386$ \\
\hline \multirow{2}{*}{ ČSL } & Pearson & 0,220 & $-0,270$ & $-0,115$ & 0,151 & 0,275 & 0,020 \\
\hline & Spearman & 0,403 & $-0,566$ & 0,052 & 0,245 & 0,346 & 0,076 \\
\hline \multirow{2}{*}{ ČSND } & Pearson & $-0,021$ & $-0,194$ & $-0,066$ & $\mathbf{0 , 4 0 7}$ & 0,708 & 0,260 \\
\hline & Spearman & 0,050 & $-0,167$ & 0,120 & 0,287 & 0,140 & $-0,024$ \\
\hline \multirow{2}{*}{ ČSNS } & Pearson & $-0,032$ & $-0,098$ & 0,023 & 0,423 & 0,325 & 0,179 \\
\hline & Spearman & $-0,127$ & 0,087 & 0,238 & 0,241 & 0,378 & 0,199 \\
\hline \multirow{2}{*}{ HSL'S } & Pearson & 0,751 & $-0,749$ & $-0,030$ & 0,008 & 0,081 & $-0,059$ \\
\hline & Spearman & 0,671 & $-0,701$ & 0,146 & 0,050 & 0,040 & $-0,071$ \\
\hline \multirow{2}{*}{ KSČ } & Pearson & $-0,488$ & 0,560 & 0,101 & $-0,196$ & $-0,348$ & $-0,054$ \\
\hline & Spearman & $-0,454$ & 0,666 & 0,096 & $-0,207$ & $-0,124$ & $-0,002$ \\
\hline \multirow{2}{*}{ RSZML } & Pearson & 0,235 & $-0,261$ & $-0,325$ & 0,491 & 0,331 & 0,224 \\
\hline & Spearman & 0,190 & $-0,167$ & $-0,301$ & 0,405 & 0,170 & 0,064 \\
\hline \multirow{2}{*}{ SNS } & Pearson & 0,300 & $-0,216$ & $-0,086$ & $-0,126$ & $-0,149$ & $-0,035$ \\
\hline & Spearman & 0,453 & $-0,310$ & 0,115 & $-0,059$ & $-0,046$ & $-0,034$ \\
\hline \multirow{2}{*}{ ZKSS } & Pearson & $-0,561$ & 0,551 & 0,175 & $-0,037$ & $-0,177$ & $-0,105$ \\
\hline & Spearman & $-0,621$ & 0,758 & 0,284 & $-0,166$ & $-0,009$ & 0,033 \\
\hline \multirow{2}{*}{ ŽS } & Pearson & 0,176 & $-0,295$ & $-0,126$ & 0,618 & 0,414 & 0,185 \\
\hline & Spearman & 0,094 & $-0,194$ & 0,073 & 0,627 & 0,332 & 0,061 \\
\hline \multirow[b]{2}{*}{ Politická strana } & & \multicolumn{6}{|c|}{ Náboženské vyznání } \\
\hline & koeficient & řím. kat. & řec. kat. & $\begin{array}{l}\text { evang. } \\
\text { augsb. }\end{array}$ & čs. hus. & bez vyznání & jiné \\
\hline \multirow{2}{*}{ ČSDSD } & Pearson & 0,255 & $-0,360$ & 0,191 & 0,185 & 0,118 & $-0,457$ \\
\hline & Spearman & 0,350 & $-0,378$ & 0,291 & 0,031 & 0,283 & $-0,589$ \\
\hline \multirow{2}{*}{ ČSL } & Pearson & 0,106 & 0,207 & $-0,206$ & 0,072 & $-0,122$ & 0,065 \\
\hline & Spearman & 0,191 & 0,211 & 0,136 & $-0,001$ & $-0,146$ & $-0,095$ \\
\hline \multirow{2}{*}{ ČSND } & Pearson & $-0,323$ & 0,619 & $-0,080$ & $-0,068$ & 0,075 & $\mathbf{0 , 4 3 0}$ \\
\hline & Spearman & $-0,124$ & 0,146 & 0,008 & 0,125 & 0,097 & 0,125 \\
\hline \multirow{2}{*}{ ČSNS } & Pearson & $-0,234$ & 0,305 & $-0,015$ & 0,066 & 0,625 & 0,266 \\
\hline & Spearman & $-0,367$ & 0,499 & 0,290 & $\mathbf{0 , 5 3 7}$ & 0,199 & 0,272 \\
\hline \multirow{2}{*}{ HSLS } & Pearson & 0,412 & 0,041 & $-0,202$ & 0,078 & 0,048 & $-0,276$ \\
\hline & Spearman & 0,459 & $-0,100$ & 0,177 & 0,116 & $-0,169$ & $-0,429$ \\
\hline \multirow{2}{*}{ KSČ } & Pearson & $-0,026$ & $-0,283$ & 0,029 & $-0,097$ & 0,085 & 0,003 \\
\hline & Spearman & 0,003 & 0,008 & 0,034 & 0,021 & 0,109 & 0,133 \\
\hline \multirow{2}{*}{ RSZML } & Pearson & $-0,629$ & 0,414 & 0,426 & $-0,117$ & $-0,130$ & 0,316 \\
\hline & Spearman & $-0,540$ & 0,131 & $-0,136$ & $-0,051$ & 0,248 & 0,209 \\
\hline \multirow{2}{*}{ SNS } & Pearson & $-\mathbf{0 , 4 2 0}$ & $-0,169$ & 0,780 & $-0,014$ & 0,117 & 0,067 \\
\hline & Spearman & $-0,305$ & $-0,089$ & 0,149 & 0,179 & 0,749 & $-0,279$ \\
\hline $7 \mathrm{KSS}$ & Pearson & 0,113 & $-0,123$ & $-0,214$ & $-0,045$ & 0,130 & 0,067 \\
\hline ZNSS & Spearman & 0,039 & 0,105 & 0,009 & 0,052 & $-0,102$ & 0,237 \\
\hline Žc & Pearson & $-0,174$ & 0,506 & $-0,193$ & 0,045 & 0,229 & 0,363 \\
\hline$\angle \mathrm{S}$ & Spearman & $-0,114$ & 0,269 & 0,227 & 0,148 & $-0,080$ & 0,265 \\
\hline
\end{tabular}

Vysvětlivky: čs. - československá, mad'. - mad’arská, něm. - německá, žid.- židovská, rus. - rusínská; řím. kat. - římskokatolické, řec. kat. - řeckokatolické, evang. augsb. - evangelické augsburského vyznání, čs. hus. - československé husitské Zdroj: SÚS (1924 a 1926), vlastní výpočty autora. 
Tab. 4. Parametry lineární regrese (OLS) mezi volebními výsledky KSČ (závisle proměnná) a národnostním/náboženským složením obyvatel v roce 1925

\begin{tabular}{lccccc}
\hline \multicolumn{1}{c}{ Nezávislé proměnné } & $\begin{array}{c}\text { Odhad } \\
\text { parametrů }\end{array}$ & $\begin{array}{c}\text { Standardní } \\
\text { chyba }\end{array}$ & t hodnota & $\operatorname{Pr}(>|t|)$ & $\begin{array}{c}\text { Významnost } \\
\text { vztahu }\end{array}$ \\
\hline (konstanta) & 8,208 & 2,196 & 3,737 & 0,000 & $* * *$ \\
mad'arská & 0,163 & 0,030 & 5,451 & 0,000 & $* * *$ \\
německá & 0,155 & 0,094 & 1,647 & 0,104 & \\
židovská & 0,085 & 0,667 & 0,127 & 0,899 & \\
rusínská & $-0,291$ & 0,197 & $-1,477$ & 0,145 & \\
řeckokatolická & 0,055 & 0,140 & 0,392 & 0,696 & \\
čs. husitská & $-5,655$ & 7,142 & $-0,792$ & 0,431 & \\
evangelická augsb. & 0,060 & 0,054 & 1,114 & 0,269 & \\
bez vyznání & 4,198 & 5,006 & 0,839 & 0,405 & \\
\hline
\end{tabular}

Zdroj: SÚS (1924 a 1926), vlastní výpočty autora.

Tab. 5. Parametry lineární regrese (OLS) mezi volebními výsledky ČSDSD (závisle proměnná) a národnostním/náboženským složením obyvatel v roce 1925

\begin{tabular}{lccccc}
\hline \multicolumn{1}{c}{ Nezávislé proměnné } & $\begin{array}{c}\text { Odhad } \\
\text { parametrů }\end{array}$ & $\begin{array}{c}\text { Standardní } \\
\text { chyba }\end{array}$ & t hodnota & $\operatorname{Pr}(>|t|)$ & $\begin{array}{c}\text { Významnost } \\
\text { vztahu }\end{array}$ \\
\hline (konstanta) & 5,295 & 1,078 & 4,910 & 0,000 & $* * *$ \\
mad’arská & $-0,039$ & 0,015 & $-2,678$ & 0,009 & $* *$ \\
německá & 0,037 & 0,046 & 0,795 & 0,430 & \\
židovská & $-0,131$ & 0,327 & $-0,399$ & 0,691 & \\
rusínská & 0,028 & 0,097 & 0,290 & 0,772 & \\
řeckokatolická & $-0,103$ & 0,069 & $-1,496$ & 0,140 & \\
čs. husitská & 3,395 & 3,506 & 0,968 & 0,337 & \\
evangelická augsb. & 0,005 & 0,026 & 0,196 & 0,845 & \\
bez vyznání & 0,616 & 2,457 & 0,251 & 0,803 & \\
\hline
\end{tabular}

Zdroj: SÚS (1924 a 1926), vlastní výpočty autora.

Výsledky třetích parlamentních voleb na Slovensku v roce 1929 jsou podobné jako ve volbách předchozích. Dominantní pozici potvrzuje HSLS, zatímco druhé místo již tradičně obsadili agrárníci. Na třetím místě skončila nově vytvořená koalice mad’arských stran ZKSS a MNS (Mad'arská národní strana). Tyto volby zobrazují pokračující trend u několika korelací z předešlých let. V případě ČSND a rusínské národnosti se znovu ukazuje silný vzájemný vztah, ovlivněný opětovným spojenectvím strany s několika rusínskými uskupeními, zvláště pak s Autonomným zemědělským sojuzem, ale nově i SNS. Tento faktor se ukazuje i v otázce náboženského vyznání, kde sledujeme náznak záporné korelace podílu obyvatel patřících $\mathrm{k}$ rímskokatolické církvi s CSND a zároveň pozitivní korelaci s podílem obyvatel hlásících se k řeckokatolické církví (tab. 6). U HSL'S sledujeme, v případě obou koeficientů, střední zápornou korelaci s židovskou národností. V tomto případě se může jednat o vzrůstající antisemitismus mezi příznivci této strany. Hlinkova stra- 
Tab. 6. Hodnoty korelačních koeficientů mezi volebními výsledky vybraných politických stran a národnostním/náboženským složením obyvatel $v$ roce 1929

\begin{tabular}{|c|c|c|c|c|c|c|c|}
\hline \multirow{2}{*}{ Politická strana } & \multirow{2}{*}{$\begin{array}{l}\text { Korelační } \\
\text { koeficient }\end{array}$} & \multicolumn{6}{|c|}{ Národnost } \\
\hline & & čs. & mad'. & něm. & žid. & rus. & ostatní \\
\hline \multirow{2}{*}{ ČSDSD } & Pearson & 0,389 & $-0,304$ & 0,224 & $-0,331$ & $-0,261$ & $-0,367$ \\
\hline & Spearman & 0,393 & $-0,085$ & 0,389 & $-0,397$ & $-0,281$ & $-0,423$ \\
\hline \multirow{2}{*}{ ČSL } & Pearson & 0,315 & $-0,268$ & $-0,184$ & $-0,173$ & 0,017 & $-0,175$ \\
\hline & Spearman & 0,372 & $-0,444$ & $-0,137$ & $-0,020$ & 0,136 & $-0,147$ \\
\hline \multirow{2}{*}{ ČSND } & Pearson & $-0,166$ & $-0,223$ & $-0,123$ & 0,232 & $\mathbf{0 , 8 3 1}$ & 0,155 \\
\hline & Spearman & 0,007 & $-0,203$ & $-0,017$ & 0,259 & 0,477 & 0,226 \\
\hline \multirow{2}{*}{ ČSNS } & Pearson & 0,044 & $-0,106$ & 0,194 & 0,297 & $-0,063$ & 0,110 \\
\hline & Spearman & $-0,041$ & 0,225 & 0,367 & 0,097 & 0,138 & 0,133 \\
\hline \multirow{2}{*}{ HSL'S } & Pearson & 0,747 & $-0,669$ & $-0,044$ & $-0,413$ & $-0,144$ & $-0,338$ \\
\hline & Spearman & 0,765 & $-0,704$ & 0,042 & $-0,445$ & $-0,077$ & $-0,496$ \\
\hline \multirow{2}{*}{ ZKSS+MNS } & Pearson & $-0,812$ & 0,919 & 0,062 & 0,293 & $-0,199$ & 0,281 \\
\hline & Spearman & $-0,763$ & 0,942 & 0,227 & 0,398 & 0,025 & 0,440 \\
\hline \multirow{2}{*}{ KSČ } & Pearson & $-0,539$ & 0,667 & 0,110 & 0,091 & $-0,258$ & 0,104 \\
\hline & Spearman & $-0,434$ & 0,663 & 0,213 & 0,201 & $-0,251$ & 0,112 \\
\hline \multirow{2}{*}{ ŽS+KPS } & Pearson & 0,020 & $-0,256$ & $-0,018$ & 0,704 & 0,321 & 0,334 \\
\hline & Spearman & $-0,026$ & $-0,162$ & 0,138 & 0,661 & $\mathbf{0 , 5 2 7}$ & 0,248 \\
\hline \multirow{2}{*}{ RSZML } & Pearson & 0,075 & $-0,247$ & $-0,261$ & 0,190 & 0,416 & 0,238 \\
\hline & Spearman & 0,039 & $-0,157$ & $-0,252$ & 0,143 & 0,372 & 0,151 \\
\hline \multirow[b]{2}{*}{ Politická strana } & Kore & \multicolumn{6}{|c|}{ Náboženské vyznání } \\
\hline & koeficient & řím. kat. & řec. kat. & $\begin{array}{l}\text { evang. } \\
\text { augsb. }\end{array}$ & čs. hus. & bez vyznání & jiné \\
\hline \multirow{2}{*}{ ČSDSD } & Pearson & 0,251 & $-0,226$ & 0,249 & 0,282 & 0,281 & $-0,375$ \\
\hline & Spearman & 0,301 & $-0,288$ & 0,372 & 0,377 & 0,338 & $-0,429$ \\
\hline \multirow{2}{*}{$\check{C} \mathrm{SL}$} & Pearson & 0,293 & $-0,016$ & $-0,221$ & $-0,167$ & $-0,154$ & $-0,253$ \\
\hline & Spearman & 0,238 & 0,016 & $-0,140$ & $-0,193$ & $-0,264$ & $-0,221$ \\
\hline \multirow{2}{*}{ ČSND } & Pearson & $-0,655$ & 0,709 & 0,190 & $-0,119$ & $-0,064$ & $-0,032$ \\
\hline & Spearman & $-0,642$ & 0,495 & 0,069 & 0,091 & 0,367 & 0,078 \\
\hline \multirow{2}{*}{ ČSNS } & Pearson & $-0,008$ & $-0,097$ & 0,067 & 0,818 & 0,809 & 0,005 \\
\hline & Spearman & $-0,045$ & 0,181 & 0,271 & 0,633 & 0,609 & 0,120 \\
\hline \multirow{2}{*}{ HSL'S } & Pearson & 0,549 & $-0,160$ & $-0,200$ & $-0,115$ & $-0,162$ & $-0,624$ \\
\hline & Spearman & 0,574 & $-0,239$ & $-0,057$ & $-0,131$ & $-0,092$ & $-0,703$ \\
\hline \multirow{2}{*}{ ZKSS+MNS } & Pearson & $-0,093$ & $-0,160$ & $-0,139$ & 0,052 & 0,059 & 0,710 \\
\hline & Spearman & $-0,209$ & 0,141 & 0,175 & 0,219 & 0,034 & 0,667 \\
\hline \multirow{2}{*}{ KSČ } & Pearson & $-0,009$ & $-0,296$ & 0,014 & 0,120 & 0,136 & 0,490 \\
\hline & Spearman & $-0,061$ & $-0,118$ & 0,213 & 0,250 & 0,134 & 0,434 \\
\hline \multirow{2}{*}{ ŽS+KPS } & Pearson & $-0,333$ & 0,478 & $-0,154$ & 0,318 & 0,373 & 0,172 \\
\hline & Spearman & $-0,287$ & 0,433 & 0,181 & 0,298 & $-0,004$ & 0,324 \\
\hline \multirow{2}{*}{ RSZML } & Pearson & $-0,689$ & 0,559 & 0,382 & $-0,281$ & $-0,282$ & $-0,006$ \\
\hline & Spearman & $-0,620$ & 0,402 & $-0,129$ & $-0,145$ & 0,231 & 0,128 \\
\hline
\end{tabular}

Vysvětlivky: čs. - československá, mad'. - mad'arská, něm. - německá, žid.- židovská, rus. - rusínská; řím. kat. - římskokatolické, řec. kat. - řeckokatolické, evang. augsb. - evangelické augsburského vyznání, čs. hus. - československé husitské Zdroj: SÚS (1930 a 1934), vlastní výpočty autora. 
na při korelaci s náboženstvím nám kromě obligátního poměru s římskými katolíky ukazuje náznak negativní korelace s kategorií ,jiné“. V této položce se mimo jiné ukrývá židovské náboženství, a tak můžeme očekávat souvislost mezi těmito hodnotami a zápornými výsledky židovského etnika a hlinkovců. Zjištěné hodnoty lineární regrese (tab. 7) ukazují na zápornou spojitost mezi hlinkovci na jedné straně a Mad’ary, Němci, evangelíky a řeckokatolíky na straně druhé. Nejvýraznější vztah je s Mad'ary, kde jeden procentní bod jejich zastoupení v daném okrese ubíral $0,6 \%$ hlasů pro HSL'S.

Tab. 7. Parametry lineární regrese (OLS) mezi volebními výsledky HSLS (závisle proměnná) a národnostním/náboženským složením obyvatel v roce 1929

\begin{tabular}{lccccc}
\hline \multicolumn{1}{c}{ Nezávislé proměnné } & $\begin{array}{c}\text { Odhad para- } \\
\text { metrů }\end{array}$ & $\begin{array}{c}\text { Standardní } \\
\text { chyba }\end{array}$ & t hodnota & $\operatorname{Pr}(>|t|)$ & $\begin{array}{c}\text { Významnost } \\
\text { vztahu }\end{array}$ \\
\hline (konstanta) & 56,204 & 2,268 & 24,777 & 0,000 & $* * *$ \\
mad’arská & $-0,622$ & 0,049 & $-12,621$ & 0,000 & $* * *$ \\
německá & $-0,349$ & 0,149 & $-2,337$ & 0,022 & $*$ \\
židovská & $-0,982$ & 1,048 & $-0,937$ & 0,352 & \\
rusínská & $-0,114$ & 0,163 & $-0,703$ & 0,485 & \\
řeckokatolická & $-0,418$ & 0,156 & $-2,678$ & 0,009 & $* *$ \\
čs. husitská & 0,322 & 9,701 & 0,033 & 0,974 & $*$ \\
evangelická augsb. & $-0,551$ & 0,070 & $-7,881$ & 0,000 & $* * *$ \\
bez vyznání & $-6,162$ & 7,001 & $-0,880$ & 0,382 & \\
\hline
\end{tabular}

Zdroj: SÚS (1930 a 1934), vlastní výpočty autora.

Spojením ZKKS a MNS do velké mad'arské volební koalice vzniká velmi silný pozitivní vztah mezi volební podporou této koalice a podílem obyvatel s mad'arskou národností. U KSČ znovu nalézáme negativní korelaci s čs. národností a kladnou korelaci s Mad'ary. Tomu odpovídají i volební výsledky a úspěch komunistů v jižních okresech Slovenska. Vzájemnou synergii mezi židovskou národností a Židovskou stranou neoslabila ani spolupráce s koalicí polských stran (KPS). Pozorujeme náznak pozitivní korelace rusínského etnika a podpory RSZML, která v těchto volbách ovládla většinu okresů východního Slovenska. Agrárníci měli rovněž vysokou podporu mezi rusínským obyvatelstvem naprŕiklad na Podkarpatské Rusi, kde pravidelně volby vyhrávali. Tento fenomén přisuzuje Gregor (2015) efektu „land for voters“ (pưda za hlasy) a úspěšně provedené pozemkové reformě na počátku existence republiky právě díky politice RSZML. Neprokázaný statistický vztah k jakémukoliv vyznání zaznamenáváme u lidové strany. ČSL po rozpadu jednorázové koalice s HSL'S po volbách 1920 výrazně ztratila svůj potenciál a její preference se pohybovaly na Slovensku okolo $2 \%$. Důvodem, proč se neprokázala korelace, může být fakt, že strana získala nejsilnější podporu v regionu Kysuc, kde bojovala o stejného voliče s daleko silnější HSL'S. Žádný vztah k národnosti ukazují výsledky u ČSNS, kde však spatřujeme korelaci (r i rs) s husitskou církví, respektive s obyvateli bez náboženského vyznání. Vysoké hodnoty ukazují závislost mezi těmito proměnnými a lze se domnívat, že elektorát ČSNS byl složen zejména z Čechů, kteří se přistěhovali na Slovensko jako státní úředníci za prací (Kázmerová 1999). 
Tab. 8. Hodnoty korelačních koeficientů mezi volebními výsledky vybraných politických stran a národnostním/náboženským složením obyvatel $\mathrm{v}$ roce 1935

\begin{tabular}{|c|c|c|c|c|c|c|c|}
\hline \multirow{2}{*}{ Politická strana } & \multirow{2}{*}{$\begin{array}{l}\text { Korelační } \\
\text { koeficient }\end{array}$} & \multicolumn{6}{|c|}{ Národnost } \\
\hline & & čs. & mad'. & něm. & žid. & rus. & ostatní \\
\hline \multirow{2}{*}{$\mathrm{AB}$} & Pearson & 0,769 & $-0,767$ & $-0,063$ & $-0,427$ & 0,018 & $-0,344$ \\
\hline & Spearman & 0,734 & $-0,706$ & 0,002 & $-0,477$ & $-0,049$ & $-0,472$ \\
\hline \multirow{2}{*}{ ČSDSD } & Pearson & 0,335 & $-0,331$ & 0,103 & $-0,210$ & $-0,068$ & $-0,188$ \\
\hline & Spearman & 0,302 & $-0,150$ & 0,305 & $-0,218$ & 0,017 & $-0,225$ \\
\hline \multirow{2}{*}{ ČSL } & Pearson & 0,348 & $-0,280$ & $-0,093$ & $-0,216$ & $-0,069$ & $-0,227$ \\
\hline & Spearman & 0,487 & $-0,519$ & 0,078 & $-0,190$ & $-0,029$ & $-0,298$ \\
\hline \multirow{2}{*}{ ČSNS } & Pearson & 0,018 & $-0,117$ & 0,340 & 0,173 & $-0,072$ & 0,166 \\
\hline & Spearman & $-0,059$ & 0,184 & 0,436 & 0,038 & 0,192 & 0,190 \\
\hline \multirow{2}{*}{ ZKSS+MNS } & Pearson & $-0,825$ & 0,941 & 0,039 & 0,313 & $-0,197$ & 0,249 \\
\hline & Spearman & $-0,761$ & 0,953 & 0,233 & 0,410 & 0,013 & 0,438 \\
\hline \multirow{2}{*}{ KSČ } & Pearson & $-0,482$ & 0,579 & $-0,041$ & 0,126 & $-0,115$ & 0,090 \\
\hline & Spearman & $-0,440$ & 0,576 & 0,078 & 0,178 & $-0,171$ & 0,158 \\
\hline \multirow{2}{*}{ NSJ } & Pearson & $-0,150$ & $-0,464$ & $-0,063$ & 0,026 & 0,450 & $-0,399$ \\
\hline & Spearman & $-0,147$ & $-0,099$ & 0,139 & 0,398 & 0,513 & 0,347 \\
\hline \multirow{2}{*}{ RSZML } & Pearson & 0,002 & $-0,160$ & $-0,304$ & 0,293 & 0,397 & 0,325 \\
\hline & Spearman & $-0,065$ & $-0,097$ & $-0,331$ & 0,269 & 0,402 & 0,265 \\
\hline \multirow[b]{2}{*}{ Politická strana } & \multicolumn{7}{|c|}{ Náboženské vyznání } \\
\hline & $\begin{array}{l}\text { Korelacnı } \\
\text { koeficient }\end{array}$ & řím. kat. & řec. kat. & $\begin{array}{l}\text { evang. } \\
\text { augsb. }\end{array}$ & čs. hus. & $\begin{array}{c}\text { bez } \\
\text { vyznání }\end{array}$ & jiné \\
\hline \multirow{2}{*}{$\mathrm{AB}$} & Pearson & 0,418 & $-0,052$ & $-0,092$ & $-0,158$ & $-0,186$ & $-0,690$ \\
\hline & Spearman & 0,499 & $-0,207$ & $-0,081$ & $-0,101$ & $-0,068$ & $-0,708$ \\
\hline \multirow{2}{*}{ ČSDSD } & Pearson & 0,065 & $-0,175$ & 0,246 & 0,230 & 0,239 & $-0,281$ \\
\hline & Spearman & 0,065 & $-0,038$ & 0,278 & 0,299 & 0,302 & $-0,258$ \\
\hline \multirow{2}{*}{ ČSL } & Pearson & 0,373 & $-0,099$ & $-0,219$ & $-0,138$ & $-0,140$ & $-0,298$ \\
\hline & Spearman & 0,506 & $-0,188$ & $-0,082$ & $-0,188$ & $-0,180$ & $-0,439$ \\
\hline \multirow{2}{*}{ ČSNS } & Pearson & 0,024 & $-0,141$ & 0,087 & 0,805 & $\mathbf{0 , 8 3 0}$ & $-0,027$ \\
\hline & Spearman & $-0,017$ & 0,213 & 0,623 & 0,622 & 0,282 & 0,042 \\
\hline \multirow{2}{*}{ ZKSS+MNS } & Pearson & $-0,067$ & $-0,154$ & $-0,186$ & 0,075 & 0,082 & 0,719 \\
\hline & Spearman & $-0,176$ & 0,121 & 0,192 & 0,227 & 0,008 & 0,672 \\
\hline \multirow{2}{*}{ KSČ } & Pearson & $-0,185$ & $-0,198$ & 0,193 & 0,097 & 0,097 & 0,423 \\
\hline & Spearman & $-0,201$ & $-0,015$ & 0,151 & 0,232 & 0,134 & 0,413 \\
\hline \multirow{2}{*}{ NSJ } & Pearson & $-0,470$ & 0,740 & $-0,112$ & 0,127 & 0,144 & $-0,016$ \\
\hline & Spearman & $-0,344$ & 0,511 & 0,184 & 0,197 & 0,019 & 0,153 \\
\hline \multirow{2}{*}{ RSZML } & Pearson & $-0,709$ & 0,624 & 0,259 & $-0,295$ & $-0,297$ & 0,134 \\
\hline & Spearman & $-0,693$ & 0,427 & $-0,148$ & $-0,202$ & 0,182 & 0,282 \\
\hline
\end{tabular}

Vysvětlivky: čs. - československá, mad'. - mad’arská, něm. - německá, žid. - židovská, rus. - rusínská; řím. kat. - římskokatolické, řec. kat. - řeckokatolické, evang. augsb. - evangelické augsburského vyznání, čs. hus. - československé husitské Zdroj: SÚS (1934 a 1936), vlastní výpočty autora. 
Korelační závislosti jsme sledovali a hodnotili rovněž i u posledních voleb roku 1935. Celkově možno říci, že HSL'S díky vzniku volební koalice s názvem Autonomistický blok $(\mathrm{AB})$ odvrátila sestup voličských preferencí a znovu s přehledem zvítězila. Na druhém místě skončili mírně oslabení agrárníci, třetí pak komunisté. Tradičně dobrý výsledek zaznamenala mad'arská ZKSS, která i tyto volby kandidovala společně s MNS. V nastolené tendenci HSL'S, tzn. záporné korelaci s podílem židovského etnika a Mad'arů pokračuje i nová koalice AB. Naopak mad'arská koalice křest'anských socialistů s nacionalisty opět zobrazuje jejich blízký poměr k mad'arské menšině na jihu Slovenska a odtažitý vztah k československé národnosti. Podobné hodnoty korelací zjišt'ujeme i v př́ípadě KSČ. Ukazuje se zajímavý fakt, že ve všech třech volbách, ve kterých komunisté kandidovali, nedokázali oslovit ve větší míre slovenské majoritní obyvatelstvo, ale př́slušníky jedné konkrétní národnostní menšiny, a to mad’arského etnika. To je rozdíl oproti českým zemím, kde byl tento trend zcela opačný (Zemko 2004). CSND, tentokrát kandidující pod hlavičkou Národního sjednocení (NSJ), má střední zápornou korelaci s mad’arským etnikem, což se v předchozích př́ípadech nikdy neprokázalo. Náznak korelace se tentokrát neprokázal mezi RSZML a Rusíny.

U náboženského vyznání a politických stran lze zaznamenat stabilní růst pozitivních hodnot u korelací ČSNS s Církví československou husitskou a osob bez vyznání. Tato menší politická strana vykazuje v průběhu času růst politických preferencí a nejvyšších hodnot dosahuje právě v těchto volbách. Stejně je tomu i prrípadě korelací s Církví československou husitskou. Rapidní vzrůst hodnoty sledujeme mezi lety 1925 a 1929, kdy na Slovensko přicházelo největší množství Čechů. Jejich počet se v roce 1937 odhaduje přes 100 tisíc (Vaculík 2009). Právě Češi s největší pravděpodobností tvořili hlavní skupinu voličů této strany. Regresní analýza nachází vztah mezi proměnnými (tab. 9), přičemž přítomnost jednoho procenta obyvatel bez vyznání $v$ určitém politickém okrese zvýšilo výsledky ČSNS o $2,4 \%$.

Tab. 9. Parametry lineární regrese (OLS) mezi volebními výsledky ČSNS (závisle proměnná) a národnostním/náboženským složením obyvatel v roce 1935

\begin{tabular}{lccccc}
\hline \multicolumn{1}{c}{ Nezávislé proměnné } & $\begin{array}{c}\text { Odhad } \\
\text { parametrů }\end{array}$ & $\begin{array}{c}\text { Standardní } \\
\text { chyba }\end{array}$ & t hodnota & $\operatorname{Pr}(>|t|)$ & $\begin{array}{c}\text { Významnost } \\
\text { vztahu }\end{array}$ \\
\hline (konstanta) & 1,481 & 0,270 & 5,492 & 0,000 & $* * *$ \\
mad'arská & $-0,007$ & 0,006 & $-1,183$ & 0,241 & \\
německá & 0,017 & 0,018 & 0,930 & 0,355 & \\
židovská & 0,007 & 0,125 & 0,057 & 0,955 & \\
rusínská & 0,029 & 0,019 & 1,514 & 0,135 & \\
řekkokatolická & $-0,025$ & 0,019 & $-1,337$ & 0,185 & \\
čs. husitská & 1,653 & 1,153 & 1,434 & 0,156 & \\
evangelická augsb. & 0,005 & 0,008 & 0,624 & 0,535 & $* *$ \\
bez vyznání & 2,376 & 0,832 & 2,856 & 0,006 & $* *$ \\
\hline
\end{tabular}

Zdroj: SÚS (1934 a 1936), vlastní výpočty autora.

Při pohledu na výsledné hodnoty korelace $\mathrm{v}$ tabulce 8 znovu zaznamenáváme slabé vazby mezi národností, náboženství a ČSDSD, stejně jako u voleb v roce 1920. Sociální demokracie, po velkém úpadku ve volbách 1925, postupem času znovu posilovala a v květnových volbách roku 1935 získala na Slovensku 184335 
hlasů $(11,35 \%)$. Regresní analýza opět zaznamenala slabý záporný poměr k mad'arské národnosti (tab. 10).

Tab. 10. Parametry lineární regrese (OLS) mezi volebními výsledky ČSDSD (závisle proměnná) a národnostním/náboženským složením obyvatel v roce 1935

\begin{tabular}{lccccc}
\hline \multicolumn{1}{c}{ Nezávislé proměnné } & $\begin{array}{c}\text { Odhad } \\
\text { parametrů }\end{array}$ & $\begin{array}{c}\text { Standardní } \\
\text { chyba }\end{array}$ & thodnota & $\operatorname{Pr}(>|t|)$ & $\begin{array}{c}\text { Významnost } \\
\text { vztahu }\end{array}$ \\
\hline (konstanta) & 11,287 & 1,044 & 10,809 & 0,000 & $* * *$ \\
mad'arská & $-0,055$ & 0,023 & $-2,436$ & 0,017 & $*$ \\
německá & $-0,030$ & 0,069 & $-0,438$ & 0,663 & \\
židovská & $-0,316$ & 0,482 & $-0,654$ & 0,515 & \\
rusínská & 0,074 & 0,075 & 0,984 & 0,329 & \\
řeckokatolická & $-0,081$ & 0,072 & $-1,127$ & 0,263 & \\
čs. husitská & 0,821 & 4,466 & 0,184 & 0,855 & \\
evangelická augsb. & 0,037 & 0,032 & 1,156 & 0,252 & \\
bez vyznání & 2,201 & 3,223 & 0,683 & 0,497 & \\
\hline
\end{tabular}

Zdroj: SÚS (1934 a 1936), vlastní výpočty autora.

\section{DISKUSE A ZÁVĚR}

Výzkum v předkládané studii se soustředil na vyhodnocení vztahu volebních výsledků vybraných politických stran a vybraných demografických charakteristik (národnosti a náboženství) na území dnešního Slovenska v období meziválečného Ceskoslovenska pomocí - ve volební geografii obvykle používaných - kvantitativních metod, jakými jsou korelační a regresní analýza. Po zhodnocení datové a pramenné základny jsme zvolili jako nejvhodnější řešení zpracování voleb do Poslanecké sněmovny Národního shromáždění republiky Československé $(1920,1925$, 1929 a 1935) na úrovni tehdejších politických okresů. Na důležitost národnostního složení a náboženského vyznání na volební chování elektorátu poukazuje řada obdobných studií (Lipták 1992, Kopstein a Wittenberg 2009, Bahna a Krivý 2016 a Madleňák a Balážovič 2018). Na rozdíl od nich jsme sledované období zpracovali komplexně z pohledu všech parlamentních voleb (za užití jiných metod) a pokusili jsme se verifikovat hypotézu, zda-li opravdu tyto dvě kategorie ovlivnily volební podporu všech politických stran či nikoliv. I když má korelační analýza poněkud omezené možnosti k rozpoznání společenské reality, lze na základě výpočtu korelačních koeficientů mezi volebními výsledky jednotlivých stran a vybranými demografickými indikátory odhalit určité tendence. Naše interpretace však nemusí patrně postřehnout další faktory, které v té době mohly ovlivňovat společnost.

Ukázalo se, že nejmenší vliv na volební výsledky mělo náboženství a národnost v př́ípadě čs. sociální demokracie. Nejvýrazněji se to projevuje v roce 1920, kdy strana uspěla ve všech částech země, a to včetně území se silným zastoupením menšinových národností. Jedná se o nejlepší výsledek jakékoliv české (československé) strany v meziválečné historii na Slovensku a zároveň největší volební zisk, co do počtu obdržených hlasů, pro jednu politickou stranu na tomto území. Výpočet korelačních koeficientů a lineární regrese nenalezl žádnou významnou spojitost mezi demografickými indikátory a volebními výsledky sociálně-demokratické strany, což znamená, že v období poválečné krize stranu podpořili občané bez ohledu na svou národnostní př́slušnost nebo vyznání. Přes výrazný propad voličské pod- 
pory (po odštěpení radikálního komunistického křídla v roce 1921) pozorujeme obdobné výsledky i v dalším období. V případě regresní analýzy se však u CSDSD objevuje záporný vztah vůči mad'arskému etniku v letech 1925, 1929 i 1935. To znamená, že jedině v roce 1920 výpočty neprokázaly žádný vztah volebních preferencí sociální demokracie k zvoleným proměnným.

Z dalších výsledků, nalezených v průběhu analýzy dat, pozorujeme korelační vazby mezi národními socialisty (ČSNS), obyvatelstvem bez vyznání a husity. Tento jev nebyl prozatím detailně popsán. Madleňák s Balážovičem (2018) upozorňují na koncentraci voličů levicových demokratických stran, kam ČSNS bezpochyby patřila, do významných železničních uzlů. Kázmerová (1999) identifikovala jako hlavní členskou základnu této strany učitele, železničáře a úředníky, přicházející na Slovensko za prací. Můžeme se tedy domnívat, že zjištěné výsledky národních socialistů jsou patrně ovlivněny vnitrostátní migrací, a to příchodem státních zaměstnanců z českého prostředí. Ti měli - jako střední vrstva (na kterou volební program národních socialistů cílil) - tendenci tuto stranu volit i z důvodu větší osobní potřeby podporovat, $\mathrm{v}$ pro ně de facto novém prostředí, tzv. státotvornou politickou stranu.

Obecně lze říci, že nutným předpokladem pro dobrý volební výsledek v meziválečném období na území Slovenska bylo pro československé strany navázání koaliční spolupráce se slovenskou nebo menšinovou stranou. Takové formy volebních koalic se v průběhu času znovu vyskytovaly a měly, ač většinou jednorázově, vliv na celkové výsledky voleb. Potvrzují to např́iklad výsledky ČSND, která na východě Slovenska pravidelně spolupracovala s rusínskými stranami $(1920$ - 1929), respektive celostátně se SNS (v roce 1929). To pak přináší logické korelace mezi touto stranou a rusínským obyvatelstvem, a tím pádem i obyvateli s řeckokatolickým vyznáním.

Naše výpočty odhalily i očekávané tendence. U agrární strany (RSZML) opakovaně nacházíme kladný korelační poměr vůči evangelíkům a Rusínům a zároveň zápornou korelaci s podílem př́slušníků římskokatolické církve a Mad'arů. Výše zmíněné poměry agrárníků vưči těmto kategoriím potvrzují ve své práci i Bahna a Krivý (2016). Z dalších stran stojí za zmínku KSČ, jejíž volební podpora byla dislokována do regionů s velkým zastoupením mad’arské národnostní menšiny, se kterou nacházíme velmi silnou korelační vazbu (a zároveň záporný vztah k československé národnosti). To je poněkud protiklad vůči situaci v českých zemích, kde komunisté dominovali především $\mathrm{v}$ oblastech obývaných čs. národností a $\mathrm{v}$ regionech se silným zastoupením menšin až tak úspěšní nebyli. K stejným výsledkům pozitivního vztahu mad'arského etnika a komunistické strany, i když za užití jiných metod, došli např́klad Zemko (2004), Bahna a Krivý (2016) či Madleňák a Balážovič (2018).

Při závěrečném celkovém zhodnocení sledované problematiky můžeme konstatovat, že z našich výpočtů vyplynulo ovlivnění volebních preferencí jednotlivých stran národnostní a náboženskou strukturou okresů. Tento faktor se tedy projevil nejen ve volbách v roce 1929 (Bahna a Krivý 2016) ale kontinuálně prostupoval celým hodnoceným obdobím. Nejméně je patrný u CSDSD, v několika př́ípadech se neobjevil u ČSNS a ČSL. Naše hypotéza se tedy potvrdila jen částečně. Skrze korelační a regresní analýzu jsme nalezli očekávané výsledky, které již byly popsány v některých studiích (naprríklad záporný vztah HSLS s Mad'ary nebo kladný vztah KSČ s Mad'ary), ale i náznaky neznámých souvislostí (kladný vztah př́slušníků čs. husitské církve a obyvatel bez vyznání k ČSNS). Československé politické 
strany se na Slovensku postupně etablovaly a zvyšovaly své volební preference (i na základě spolupráce se stranami národnostních menšin) za současné výrazné dominance slovenské politické strany HSL'S a jejích autonomistických snah. Vlivem národnostního složení na Slovensku působily četné strany národnostních menšin, a to jak mad'arské, tak i německé a židovské. Pestrost národnostní tak předurčila i pestrost volební.

Př́spěvek vznikl v rámci řě̌ení vědeckého projektu č.1/0745/16 - Autonómnost', vzájomná závislost' a interakcie priestorových systémov financovaného grantovou agenturou VEGA.

\section{LITERATURA}

BAHNA, M., KRIVÝ, V. (2016). Ako volili národnosti a konfesie v parlamentných vol'bách roku 1929 na Slovensku. Možnosti nových metód ekologickej interferencie. Historický ćasopis, 64, 57-85.

BARÁTH, J., SZÖLLÖS, J., ČERNÁK, P. (1995). Analýza stability územia volebnej podpory vybraných politických strán (na základe výsledkov volieb 1990, 1992 a 1994). Geografický časopis, 47, 247-259.

BLAŽEK, J., KOSTELECKÝ, T. (1991). Geografická analýza výsledků parlamentních voleb v roce 1990. Sbornik České geografické společnosti, 1, 1-14.

CABADA, L., ŠANC, D. (2005). Český stranický systém ve 20. století. Plzeň (Aleš Čeněk).

COHEN, J. (1988). Statistical power analysis for the behavioral sciences. Hillsdale (Erlbaum).

EVANS, J. D. (1996). Straightforward statistics for the behavioral sciences. Pacific Grove (Brooks/Cole Publishing).

GREGOR, K. (2015). Land for votes: effects of the land reform on electoral results in interwar Czechoslovakia. Politologický časopis, 22, 43-54. DOI: 10.5817/PC2015-1-43.

HANULA, M. (2011). Za rol'níka, pôdu a republiku: Slovenski agrárnici v prvom polčase 1. ĆSR. Bratislava (Historický ústav SAV).

HENDL, J. (2012). Přehled statistických metod: analýza a meta analýza dat. Praha (Portál).

JEHLIČKA, P., SÝKORA, L. (1991). Stabilita regionální podpory tradičních politických stran v českých zemích (1920 - 1990). Sborník Ceské geografické společnosti, 2, 81-95.

JAŃCZAK, K. (2015). Phantom borders and electoral behaviour in Poland. Historical legacies, political culture and their influence on contemporary politics. Erdkunde, 69, 125-137. DOI: 10.3112/erdkunde.2015.02.03.

KÁRNÍK, Z. (2008). Malé dějiny československé (1867-1939). Praha (Dokořán).

KÁZMEROVÁ, L'.(1999). Pôsobenie Československej strany národno-socialistickej na Slovensku v rokoch 1918 - 1938. In Valenta, J., Voráček, E., Harna, J., eds. Československo 1918 - 1938: Osudy demokracie ve strední Evropě. Praha (Historický ústav AV ČR), pp. 184-186.

KOPSTEIN, J. S., WITTENBERG, J. (2009). Does familiarity breed contempt? Interethnic contact and support for illiberal parties. Journal of Politics, 71, 414-428. DOI: $10.1017 / \mathrm{s} 0022381609090367$.

KOSTELECKÝ, T., MIKEŠOVÁ, R., POLÁKOVÁ, M., ČERMÁK, D., BERNARD, J., S̆IMON, M. (2014). Koho voli Vaši sousedé?: prostorové vzorce volebního chováni na území Česka od roku 1920 do roku 2006, jejich změny a možné př́ičiny. Praha (Sociologický ústav AV Č́R).

KOSTELECKÝ, T., KRIVÝ, V. (2015). Urbánno-rurálne rozdiely voličského správania v Česku a na Slovensku. Sociológia, 47, 390-413.

KOWALSKI, M. (2003). Polaryzacja zachowań wyborczych w Polsce jako rezultat cywilizacyjnego rozdarcia kraju. In Kowalski, M., ed. Przestreń wyborcza Polski. PAN (Warszawa), pp. 11-48. 
KRIVÝ, V., FEGLOVÁ, V., BALKO, D. (1996). Slovensko a jeho regióny - sociokultúrne súvislosti volebného správania. Bratislava (Nadácia Médiá).

KRIVÝ, V. (2000). Politické orientácie na Slovensku - skupinové profily. Bratislava (IVO).

KRIVÝ, V. (2012). Výsledky volieb '12: čo sa zmenilo, čo zostáva. In Slovenské vol'by '12: čo im predchádzalo, postoje a výsledky. Bratislava (Sociologický ústav SAV), pp. 43-136.

KRIVÝ, V. (2014). Od Malaciek po Čadcu: výsledky volieb 1920 - 2012. In Goněc, V., Holec, R., eds. Česko-slovenská historická ročenka 2013. Skalica, Bratislava (SEVSVeda), pp. 95-120.

LIPTÁK, L'. (1992). Politické strany na Slovensku: 1860 - 1989. Bratislava (Archa).

MADLEŇÁK, T. (2012). Regionálna diferenciácia volebného správania na Slovensku 1998 - 2010. Bratislava (Veda).

MADLEŇÁK, T., BALÁŽOVIČ, L. (2018). Politické preferencie miest na Slovensku v parlamentních vol'bách 1929. Geografie, 123, 107-140.

MALÍR, J., MAREK, P. (2005). Politické strany: vývoj politických stran a hnutí v českých zemích a Československu v letech 1861-2004. Brno (Doplněk).

MAREK, P., ed. (2000). Přehled politického stranictví na území českých zemí a Československa v letech 1861 - 1998. Olomouc (KPES FF UP).

MARIOT, P. (1999). Štruktúra volebných preferencií obyvatel'ov najväčších miest Slovenska. Geografický časopis, 51, 153-174.

MESEŽNIKOV, G. (2002). Vol'by 2002. Analýza volebných programov politických strán a hnutí. Bratislava (IVO).

OSYKOVÁ, L. (2012) Volebné kampane politických strán na Slovensku počas 1. ČSR. Bratislava (Veda).

PEREPECHKO, A. S., KOLOSSOV, V. A., ZUMBRUNNEN, C. (2007). Remeasuring and rethinking social cleavages in Russia: continuity and changes in electoral geography 1917-1995. Political Geography, 26, 179-208. DOI: 10.1016/j.polgeo.2006.09.006.

PLEŚIVČÁK, M. (2017). Ideology, cleavages, and voting behaviour in 2009 and 2013 regional elections in Slovakia. Acta Universitatis Carolinae Geographica, 52, 90-105. DOI: $10.14712 / 23361980.2017 .8$.

SARTORI, G. (1976). Parties and party systems: a framework for analysis. Cambridge (Cambridge University Press).

SASD (2014). Výsledky volieb 1929 - 2012 za obce na Slovensku. (ed. Krivý, V.), [Online]. Dostupné na: http://sasd.sav.sk/sk/data_katalog_abs.php?id=sasd_2010001 [cit. 29. 4. 2019].

SÚS (1922). Volby do Národního shromáżdění v dubnu roku 1920 a volby do obecních zastupitelstev v Čechách, na Moravě a ve Slezsku v červnu 1919. Praha (Státní úr̆ad statistický).

SÚS (1924). Sčitání lidu v Republice Československé ze dne 15. února 1921. Praha (Státní úrrad statistický).

SÚS (1926). Volby do Poslanecké sněmovny v listopadu roku 1925. Praha (Státní úrad statistický).

SÚS (1930). Volby do Poslanecké sněmovny v říjnu roku 1929. Praha (Státní úr̆ad statistický).

SÚS (1934). Sčitání lidu v republice Československé ze dne 1. prosince 1930. Praha (Státní úřad statistický).

SÚS (1936). Volby do Poslanecké sněmovny v květnu roku 1935. Praha (Státní úřad statistický).

SZÖLLÖS, J. (2006). Regióny volebnej podpory vybraných politických strán v parlamentných vol'bách 1998, 2002 a 2006. Geografická revue, 2, 650-669.

ŠIMON, M. (2015). Measuring phantom borders: the case of Czech/Czechoslovakian electoral geography. Erdkunde, 69, 139-150. DOI: 10.3112/erdkunde.2015.02.04.

VACULÍIK, J. (2009). České menšiny v Evropě a ve svètě. Praha (Libri). 
WATREL, R. H., WEICHELT, R., DAVIDSON, F. M., HEPPEN, J., FOUBERG, E. H., ARCHER, J. C., MORRILL, R. L., SHELLEY, F. M., MARTIS, K. C. (2018). A tlas of the 2016 Elections. Lanham (Rowman \& Littlefield).

ZARYCKI, T. (2000). Politics in the periphery: political cleavages in Poland interpreted in their historical and international context. Europe - Asia studies, 52, 851-873. DOI: $10.1080 / 713663091$.

ZARYCKI, T. (2015). The electoral geography of Poland: between stable spatial structures and their changing interpretations. Erdkunde, 69, 107-124. DOI: 10.3112/ erdkunde.2015.02.02.

ZEMKO, M. (2004). Voličstvo strán národnostných menšín a komunistickej strany na Slovensku v parlamentních vol'bách za predmníchovskej republiky. In Zemko, M., Bystrický, V., eds. Slovensko v Československu (1918 - 1939). Bratislava (Veda), pp. 179-198.

ZEMKO, M. (2008). Volebný zákon do Poslaneckej snemovne Národného zhromaždenia za prvej Československej republiky a strany národnostných menšín. Historický časopis, 56, 81-92.

Vojtěch Przybyla

\section{THE INFLUENCE OF SELECTED DEMOGRAPHICAL CHARACTERISTICS ON ELECTORAL BEHAVIOUR IN SLOVAKIA IN THE INTERWAR PERIOD}

Our research focused on the evaluation of the relationship between the election results of selected political parties and selected demographic characteristics (nationality and religion) in the territory of present-day Slovakia during the period of interwar Czechoslovakia using - in the electoral geography of commonly used - quantitative methods such as correlation and regression analysis. After evaluating the data and source base, we chose as the most suitable solution for the processing of elections to the Chamber of Deputies of the National Assembly of the Czechoslovak Republic (1920, 1925, 1929 and 1935) at the level of the then political districts. Several similar studies point out the importance of ethnic composition and religion in electoral behaviour of the electorate (Lipták 1992, Kopstein and Wittenberg 2009, Bahna and Krivý 2016 and Madleňák and Balážovič 2018). Unlike them, we have compiled the monitored period comprehensively from the perspective of all parliamentary elections using quantitative methods. Although the correlation analysis has somewhat limited possibilities to recognize social reality, some tendencies can be revealed by calculating correlation coefficients between the election results of individual parties and selected demographic indicators.

In the final evaluation of the issue, we can conclude that our calculations have resulted in influencing the electoral preferences of individual parties by the national and religious structures of the districts. This factor was reflected not only in the elections of 1929 (Bahna and Krivý 2016) but continued to penetrate the entire period under review. It turned out that religion and nationality had the smallest influence on election results in the case of Czechoslovak social democracy. In 1920, calculations showed no relationship between electoral preferences of social democracy party and selected variables. Also, we confirmed the expected results, which have already been described in some studies (for example, the positive relationship between the Communist Party of Czechoslovakia - KSC and the Hungarians), but as well indications of unknown connections (the positive attitude of members of the Czechoslovak Hussite Church and the non-religious population to Czechoslovak National Socialist Party - ČSNS).

It turned out that the necessary precondition for a good election result was the establishment of coalition cooperation with the Slovak or minority party for the Czechoslovak par- 
ties. Such forms of electoral coalition have reappeared over time, affecting the overall election results. This was verified, for example, by the results of Czechoslovak National Democratic Party (ČSND) in the East of Slovakia, where regular cooperation with the Ruthenian parties took place. This brings a correlation between this party and the Ruthenian population and the Greek Catholic religion. Of course, we comprehend this pattern in this space as the so-called predominant side effect. In our case it is a dominance of Hlinka's Slovak Peoples Party (HSLS), which with its all-encompassing program with an emphasis on the idea of autonomy has been able to address a wide range of Slovak voters and significantly influenced the overall results in all the elections, in which it stood. 